REVIEW

\title{
Thyroid dysfunction and kidney disease
}

\author{
P Iglesias and J J Díez \\ Department of Endocrinology, Hospital Ramón y Cajal, Carretera de Colmenar, Km 9100, 28034 Madrid, Spain \\ (Correspondence should be addressed to P Iglesias; Email: piglo65@gmail.com)
}

\begin{abstract}
Thyroid hormones (TH) are essential for an adequate growth and development of the kidney. Conversely, the kidney is not only an organ for metabolism and elimination of TH, but also a target organ of some of the iodothyronines' actions. Thyroid dysfunction causes remarkable changes in glomerular and tubular functions and electrolyte and water homeostasis. Hypothyroidism is accompanied by a decrease in glomerular filtration, hyponatremia, and an alteration of the ability for water excretion. Excessive levels of TH generate an increase in glomerular filtration rate and renal plasma flow. Renal disease, in turn, leads to significant changes in thyroid function. The association of different types of glomerulopathies with both hyper- and hypofunction of the thyroid has been reported. Less frequently, tubulointerstitial disease has been associated with functional thyroid disorders. Nephrotic syndrome is accompanied by changes in the concentrations of TH due primarily to loss of protein in the urine. Acute kidney injury and chronic kidney disease are accompanied by notable effects on the hypothalamus-pituitary-thyroid axis. The secretion of pituitary thyrotropin (TSH) is impaired in uremia. Contrary to other non-thyroidal chronic disease, in uraemic patients it is not unusual to observe the sick euthyroid syndrome with low serum triodothyronine $\left(\mathrm{T}_{3}\right)$ without elevation of reverse $\mathrm{T}_{3}\left(\mathrm{rT}_{3}\right)$. Some authors have reported associations between thyroid cancer and kidney tumors and each of these organs can develop metastases into the other. Finally, data from recent research suggest that $\mathrm{TH}$, especially $\mathrm{T}_{3}$, can be considered as a marker for survival in patients with kidney disease.
\end{abstract}

European Journal of Endocrinology 160 503-515

\section{Introduction}

The interactions between kidney and thyroid functions are known for years (1-4). Thyroid hormones (TH) are necessary for growth and development of the kidney and for the maintenance of water and electrolyte homeostasis. On the other hand, kidney is involved in the metabolism and elimination of TH. From a clinical practice viewpoint, it should be mentioned that both hypothyroidism and hyperthyroidism are accompanied by remarkable alterations in the metabolism of water and electrolyte, as well as in cardiovascular function. All these effects generate changes in water and electrolyte kidney management $(5,6)$. Moreover, the decline of kidney function is accompanied by changes in the synthesis, secretion, metabolism, and elimination of TH. Thyroid dysfunction acquires special characteristics in those patients with advanced kidney disease (7). On the other hand, the different treatments used in the management of patients with kidney and thyroid diseases may be accompanied by changes or adverse events that affect thyroid and kidney function respectively.

The present article reviews the most important topics of the different derangements in kidney function that occur in patients with thyroid disease, as well as changes in thyroid physiology that develops in patients with kidney disease and with varying types and degrees of kidney failure.

\section{Effects of TH on renal physiology}

TH play an important role in growth, development, and physiology of the kidney (8-11; Fig. 1). It is known that hypothyroidism reduces and hyperthyroidism increases the kidney-to-body weight ratio by a not fully understood mechanism (12). On the other hand, children with congenital hypothyroidism have an increased prevalence of congenital renal anomalies. These findings support an important role of TH during early embryogenesis (13).

Thyroid function also influences water and electrolyte balance on different compartments of the body $(6,14)$. The kidney also plays a role on the regulation of metabolism and elimination of TH and is an important target organ for TH actions $(2,15)$. The decrease in the activity of TH is accompanied by an inability to excrete an oral water overload (16). This effect is not due to an incomplete suppression of vasopressin production, or a decrease in the reabsorptive ability in the dilutor segment of the kidney tubule, but rather to a reduction in the glomerular filtration rate (GFR) (17). 


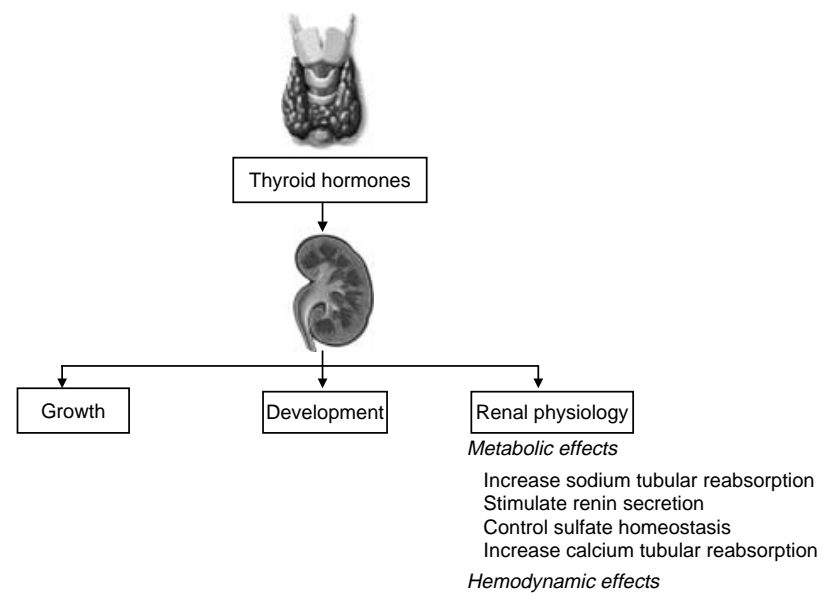

Figure 1 Effects of thyroid hormones on the kidney.

TH have a hold upon tubular transport of sodium, via their actions on the sodium-potassium ATP pump ( $\mathrm{Na} / \mathrm{K}$ ATPase) and on the potassium permeability in the membrane of proximal tubules $(10,18-23)$. In fact, tubular reabsorption of Na per gram of kidney tissue in rats was the lowest in thyroidectomized rats than in controls and was accompanied by a similar reduction of the specific activity of the Na-K ATPase pump. On the contrary, that activity increased when the reabsorption of $\mathrm{Na}$ increased in euthyroid rats treated with triiodothyronine $\left(\mathrm{T}_{3}\right)(18)$. As it occurs with $\mathrm{Na}$, the reduction of TH activity at kidney level is accompanied by a decrease in the absorption of calcium at tubular level without affecting magnesium (24).

TH stimulate renin release by the juxtaglomerular cells through a mechanism independent of the ouabainsensitive sodium pump and protein synthesis (23) and influence kidney angiotensinase activity (26). $\mathrm{T}_{3}$ is also involved in sulfate homeostasis through the regulation of kidney sodium-sulfate cotransporter, $\mathrm{NaS}(\mathrm{i})-1$, a protein entailed in the control of serum sulfate levels (27). Finally, different studies in animals have shown that $\mathrm{TH}$ act on the regulation of kidney dopaminergic system (28).

\section{Effects of thyroid dysfunction on the kidney}

Thyroid dysfunction causes significant changes in kidney function (Table 1). Both hypothyroidism and hyperthyroidism affect renal blood flow, GFR, tubular function, electrolytes homeostasis, electrolyte pump functions, and kidney structure $(2,15,29-31)$.

\section{Hypothyroidism}

The most common kidney derangements associated to hypothyroidism are: elevation of serum creatinine levels,
Table 1 Effects of thyroid dysfunction on the kidney.

\begin{tabular}{ll}
\hline Hypothyroidism & Thyrotoxicosis \\
\hline Increased serum creatinine & Decreased serum creatinine \\
Decreased glomerular filtration & Increased glomerular filtration \\
Decreased renal plasma flow & Increased renal plasma flow \\
Decreased sodium reabsorption & Increased tubular reabsorption \\
Decreased renal ability to dilute & Resistance to rhEPO action? \\
urine & \\
Hyponatremia & \\
\hline
\end{tabular}

rhEPO, recombinant human erythropoietin.

reduction in GFR and renal plasma flow (RPF), disruption of the capacity to excrete free water and hyponatremia. These alterations may be absent in patients with central hypothyroidism due to the fact that this kind of thyroid hypofunction is often accompanied by other pituitary hormone deficiencies that might affect directly or indirectly the kidney function (32).

Primary hypothyroidism is associated with a reversible elevation of serum creatinine in both adults (33-35) and children $(36,37)$. This increase is observed in more than half $(\sim 55 \%)$ of adults with hypothyroidism (32). Moreover, some authors have reported an elevation of serum creatinine associated with subclinical hypothyroidism (38).

Primary hypothyroidism is associated with a reduction of GFR and RPF that are normalized following levothyroxine administration $(14,15,29,32,33,37$, 39). Similarly, normalization of circulating TH concentrations with replacement therapy in hypothyroid patients with chronic kidney disease (CKD) can significantly improve GFR (40). However, it has recently been reported that kidney function recovers slowly in hypothyroid children, and sometimes partially, after the introduction of replacement with levothyroxine (41). The long-term clinical implications of these findings are unknown.

Hypothyroidism-associated kidney dysfunction seems to be more related with the decline in thyroid hormone levels rather than with thyroid autoimmunity (42). Among the mechanisms involved in hypothyroidism-associated kidney derangements are direct effects of $\mathrm{TH}$ on the cardiovascular system (increased peripheral resistance and reduction of myocardial contractility and stroke volume) and metabolism (hyperlipidemia), and indirect effects through paracrine or endocrine mediators, such as insulin-like growth factor type 1 (IGF-1) and vascular endothelial growth factor $(12,39,41)$.

Hyponatremia is the commonest electrolyte derangement in hypothyroid patients. Hyponatremia appears in $45 \%$ of hypothyroid patients who have elevated serum creatinine, but in less than a quarter $(21 \%)$ of those with normal creatinine levels. It is mainly due to a reduction in GFR causing diminished water delivery to the distal tubular segments. This becomes evident after water load, although ADH may be appropriately 
suppressed. Other possible mechanism of hypothyroidism induced hyponatremia is an inappropriate $\mathrm{ADH}$ secretion syndrome (SIADH)-like disorder $(32,43)$.

\section{Thyrotoxicosis}

Thyrotoxicosis is characterized by an increase in RPF and GFR resulting in a reduction of serum creatinine levels $(12,44)$. These changes are normalized after the control of thyroid function with appropriate treatment $(14,15)$. Hyperthyroidism may be linked to a decrease in total body water and exchangeable K. By contrast, the amount of exchangeable $\mathrm{Na}$ tends to increase. However, serum concentrations of $\mathrm{Na}, \mathrm{K}$, and $\mathrm{Cl}$ are normal. These alterations are typical of endogenous hyperthyroidism and exogenous thyrotoxicosis. However, central hyperthyroidism may not be accompanied by these changes when it is associated with other pituitary disorders. The reduction of serum creatinine has also been reported in subclinical hyperthyroidism (38). However, changes in water and electrolyte metabolism have not been reported by other authors (45).

Hemodynamic changes, i.e., increase in systolic volume, heart rate, and cardiac output coupled with a reduction of peripheral vascular resistance, also participate in alteration in renal function reported in patients with hyperthyroidism. These changes are due to the increased circulating demands as a result of hypermetabolism and the need to dissipate excess heat associated with hyperthyroidism (46).

\section{Kidney disease associated to thyroid dysfunction}

The different types of kidney diseases can be associated with various disorders of thyroid function $(3,7)$.

\section{Glomerular disease}

Thyroid disease may be linked to different forms of glomerulonephritis (47-55). Both hypothyroidism (56) and hyperthyroidism $(57,58)$ can coincide with different forms of glomerular disease. The more frequent form is membranous glomerulopathy associated with nephrotic syndrome (NS) $(50,52,55-57,59)$. Thyroid dysfunction has been reported to be associated with IgA glomerulonephritis $(49,51,60)$, mesangiocapillary or membranoproliferative glomerulonephritis $(47,48$, 61 ), and minimal change glomerulonephritis (58, 59, $62,63)$.

Several mechanisms have been involved in these associations. Proteinuria may promote the development of primary hypothyroidism, and the immune activation of the thyroid or kidney disorders could induce the formation of immunocomplexes $(55-57,61,64,65)$. The presence of immunocomplexes is common in patients with thyroid disease $(66,67)$. In a study performed in 171 patients with thyroid disease, the presence of immunocomplexes was detected in $26 \%$ of patients in comparison with $8 \%$ of the control subjects. This percentage increased to $33-55 \%$ in patients with an autoimmune process and was correlated with the presence of thyroid peroxidase antibodies, but not with the titer of these antibodies (67). Also, immunocomplexes deposits in the basement membrane of thyroid follicular epithelium and the glomeruli have been reported in patients with Hashimoto's thyroiditis and membranous glomerulopathy (55). Therefore, several data support the autoimmune pathogenesis for this association: i) the association of kidney and thyroid diseases of autoimmune origin, ii) its association with other autoimmune diseases such as type 1 diabetes $(61,63)$, and iii) the presence of deposits of immunoglobulins and thyroglobulin in the glomeruli of some patients $(53,54,66)$. Although autoimmune thyroid disease has occasionally been reported in patients with glomerulonephritis, no causal relationship between the two disorders has been proved so far. Glomerular disease in general is associated and occasionally caused by autoimmune disease (e.g. lupus nephritis, antineutrophil cytoplasmic antibodies (ANCA) associated vasculitis) that can be associated to autoimmune thyroid disease.

\section{Tubular disease}

Although less frequently than glomerular disease, tubular or tubulointerstitial damage has also been reported to be associated with thyroid dysfunction (68-72). Isolated cases of hyperthyroidism have been reported in association with tubulointerstitial nephritis and uveitis, a self-limited syndrome of unknown etiology that responds to glucocorticoids (68-71). In these cases, the etiology of hyperthyroidism was not Graves' disease, but rather a destructive thyroiditis with the absence of thyroid autoimmunity, low uptake in thyroid scintigraphy, and adequate response to steroid therapy $(68,69)$. Tubulointerstitial nephritis and hyperthyroidism has been reported to be associated in patients under treatment with rifampicin (73).

\section{Nephrotic syndrome}

NS is associated with changes in serum TH levels $(1,4$, $74,75)$. Urinary losses of binding proteins, such as thyroxine binding globulin (TBG), transthyretin or prealbumin, albumin, and $\mathrm{TH}$ binded to them, result in a reduction in serum total thyroxine $\left(\mathrm{T}_{4}\right)$ and, sometimes, in total $\mathrm{T}_{3}$ levels. These hormonal changes are related both to the degree of proteinuria and to serum albumin levels (1). However, patients often remain euthyroid, because free $\mathrm{T}_{4}$ and $\mathrm{T}_{3}$ levels are usually normal (1). This suggests that thyroid is able to compensate for hormonal urinary losses keeping the patient euthyroid. 
However, in patients with low thyroid reserve overt hypothyroidism can develop. Similarly, NS may increase the exogenous levothyroxine needs in patients with hypothyroidism $(1,74)$.

Primary hypothyroidism linked to congenital NS (CNS) has been reported (76-81). TH urinary loss associated with the intrauterine massive proteinuria stimulates the hypothalamus-pituitary-thyroid axis increasing serum thyrotropin (TSH) concentrations (76). Other involved factors are malnutrition and iodine depletion. However, the main cause is $\mathrm{TH}$ urinary losses, since it was observed that bilateral nephrectomy followed by extrarrenal purification treatment reverses completely the CNS associated hypothyroidism and permits the withdrawal of hormonal treatment with levothyroxine (76). Some authors recommend treatment with levothyroxine supplementation in children with CNS as it facilitates their normal development (81).

\section{Acute kidney injury}

Acute kidney injury (AKI) is associated with abnormalities in thyroid function tests similar to those found in euthyroid sick syndrome (ESS). Contrary to the usual form of the ESS, patients with AKI may not exhibit an elevation or reverse $(\mathrm{r}) \mathrm{T}_{3}$ levels $(7,82)$.

The hypothyroidism-associated rise in serum creatinine may be of relevance in patients with thyroid carcinoma in which the withdrawal of levothyroxine treatment for total body scan preparation can lead to accumulation of drugs whose metabolism and elimination is primarily renal (83). Furthermore, the development of AKI has been associated with rhabdomyolysis in patients with primary $(84,85)$ or secondary (86) hypothyroidism treated or not with statins (87).

\section{Chronic kidney disease}

CKD affects both hypothalamus-pituitary-thyroid axis and TH peripheral metabolism (86-89) (Fig. 2). Uremia influences the function and size of the thyroid $(7,88$, 92-96). Uraemic patients have an increased thyroid volume compared with subjects with normal renal function and a higher prevalence of goiter, mainly in women $(7,93,96)$. Also, thyroid nodules and thyroid carcinoma are more common in uraemic patients than in the general population (97).

Serum TSH concentrations are usually normal or elevated in $\mathrm{CKD}$, but its response to its releasing hormone (TRH) is generally low $(88,89,94,98,99)$. These findings suggest the presence of intrathyroidal and pituitary disturbances associated with uremia (98). Also, both TSH circadian rhythm and TSH glycosylation are altered in CKD. The latter may compromise TSH bioactivity.

Free and total $\mathrm{T}_{3}$ and $\mathrm{T}_{4}$ concentrations are usually normal or low in patients with $\operatorname{CKD}(7,88,89,91,93$, 94,100 ). The reduction in $\mathrm{T}_{3}$ levels (low $\mathrm{T}_{3}$ syndrome) is the most frequently observed thyroid alteration in these patients $(7,88-90,92,99,101)$. This reduction in $\mathrm{T}_{3}$ concentrations has been linked to a decrease in the peripheral synthesis of $\mathrm{T}_{3}$ from $\mathrm{T}_{4}$. Chronic metabolic acidosis associated with the CKD may contribute in this effect (102). Although free and total $\mathrm{T}_{4}$ concentrations may be normal or slightly reduced, sometimes free $\mathrm{T}_{4}$ may be high due to the effect of heparin used in anticoagulation during hemodialysis (HD), which inhibits $\mathrm{T}_{4}$ binding to its binding proteins (103).

In CKD patients, the ESS is characterized by the absence of total $\mathrm{rT}_{3}$ rising, a typical feature in other patients with non-thyroidal disease $(91,104)$. Despite the fact that the total $\mathrm{rT}_{3}$ clearance in CKD patients is diminished, there is a redistribution of $\mathrm{rT}_{3}$ from the

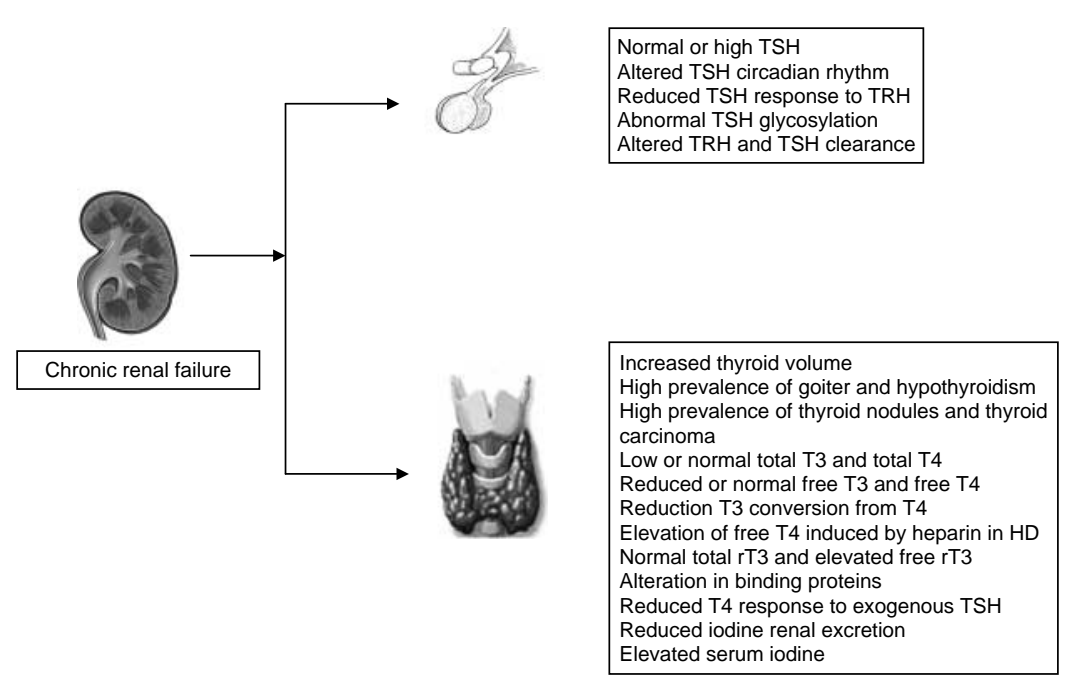

Figure 2 Effects of chronic renal failure on hypothalamus-pituitary-thyroid axis. 
vascular to the extravascular space and an increase in $\mathrm{rT}_{3}$ cellular uptake. However, free $\mathrm{rT}_{3}$ concentrations are high due to a reduction in its renal clearance $(88,91)$.

CKD is associated with a higher prevalence of primary hypothyroidism, both overt and subclinical, but not with hyperthyroidism $(7,88,96,101)$. In fact, the prevalence of primary hypothyroidism, mainly in the subclinical form, increases as GFR decreases (101). A recent study has shown a prevalence of subclinical hypothyroidism of $7 \%$ in patients with estimated GFR $\geq 90 \mathrm{ml} / \mathrm{min}$ per $1.73 \mathrm{~m}^{2}$ that increased to $17.9 \%$ in subjects with GFR $<60 \mathrm{ml} / \mathrm{min}$ per $1.73 \mathrm{~m}^{2}$ (105). The prevalence of hypothyroidism is higher in women and is associated with an increased frequency of high titers of anti-thyroid antibodies (88).

A greater prevalence of non-autoimmune primary hypothyroidism has been reported in patients with advanced diabetic nephropathy under conservative treatment in comparison with non-diabetic patients with nephropathy. It is possible that these patients had impaired renal handling of iodine resulting in an elevation of serum iodine levels with a prolongation of the Wolff-Chaikoff effect (106).

The prevalence of hyperthyroidism in CKD is similar to that found in general population $(\sim 1 \%)$, in areas with inadequate intake of iodine (94). On the other hand, uraemic patients undergoing dialysis with hyperthyroidism due to either Graves' disease or toxic multinodular goiter, can be adequately treated with therapeutic doses of ${ }^{131}$ I $(107,108)$. Moreover, hyperthyroidism has been considered as one of the many causes of anemia resistant to recombinant human erythropoietin (rh-EPO) in CKD patients on HD with an adequate response to antithyroid treatment (109).

The kidney contributes to the iodine clearance primarily through glomerular filtration. Serum iodine concentrations are high in CKD but are not correlated with the degree of kidney failure (94). This iodine excess has been linked to increased prevalence of goiter and hypothyroidism reported in CKD $(88,110)$. A high exposure to iodine facilitates the development of hypothyroidism in CKD patients (111). Some authors have reported that a restriction of dietary iodine in uraemic patients on HD can correct the hypothyroidism avoiding the need for hormone replacement with levothyroxine (112).

\section{Drugs in thyroid and renal diseases}

Different drugs used in thyroid diseases may have adverse effects on the kidney, and vice versa, agents used in the treatment of renal disease may develop undesirable effects on the thyroid (Tables 2 and 3). Hypothyroidism induced by thionamides (methimazole, carbimazole, and propylthiouracil) can cause kidney failure. Thionamides can affect kidney function by different immunological mechanisms leading to the development of different types of glomerulonephritis (113-115).

Lithium exerts adverse effects both on the thyroid and kidney, favoring the development of hypothyroidism and nephrogenic diabetes insipidus (DI). Lithium inhibits synthesis and release of TH. Nephrogenic DI induced by lithium may be due to different mechanisms. It may be related to a reduction in levels of aquaporin 2 or to lithium-induced hypercalcemia $(116,117)$.

The development of autoimmune thyroid disease following the use of alemtuzumab has been reported in transplant patients (118). Treatment with lenalidomide, a new drug with immunomodulatory, antiangiogenic, and antitumor properties, has been associated with transient thyrotoxicosis in patients with metastatic renal-cell carcinoma. The pathogenic mechanism could be that of a subacute thyroiditis (119). Similarly, hyperthyroidism induced by interferon- $\alpha$ has been reported in patients with renal cell carcinoma (120). The use of sunitinib in the treatment of patients with metastatic renal-cell carcinoma can lead to thyroid dysfunction, mainly hypothyroidism $(121,122)$. Periodic monitoring of thyroid function has been recommended in these patients (121). Since some authors believe that a state of thyroid hypofunction may be associated with a better prognosis in certain tumors, levothyroxine should be prescribed with caution in patients with mild TSH elevation (123).

Thyrotoxicosis induced by sunitinib has been reported in patients with renal cell carcinoma. Some patients may develop hypothyroidism after a transient thyrotoxicosis by sunitinib-induced destructive thyroiditis. The onset of thyrotoxicosis and its severity is unpredictable (124).

Lastly, some drugs can induce adverse effects on the kidney and thyroid. Amiodarone, an iodine-rich antiarrhythmic agent, can cause both hypothyroidism and hyperthyroidism $(125,126)$, as well as acute renal damage

Table 2 Drugs that can cause thyroid dysfunction and/or renal disease.

\begin{tabular}{llll}
\hline Drug & Indication & Thyroid dysfunction & Renal disease \\
\hline Antithyroid drugs & Hyperthyroidism & Hypothyroidism & Glomerulonephritis \\
Lithium & Bipolar disorder & Hypothyroidism & Nephrogenic diabetes insipidus \\
Amiodarone & Arrhythmias & Hypo/hyperthyroidism & Acute kidney injury \\
Rifampicin & Tuberculosis & Hyperthyroidism & Tubulointerstitial nephritis \\
\hline
\end{tabular}


Table 3 Drugs used in kidney disease that can affect thyroid function.

\begin{tabular}{lll}
\hline Drug & Indication & Thyroid pathology \\
\hline Alemtuzumab & $\begin{array}{l}\text { Renal transplant } \\
\text { Lenalidomide } \\
\text { Metastasic renal } \\
\text { carcinoma }\end{array}$ & $\begin{array}{l}\text { Autoimmune thyroiditis } \\
\text { Hyperthyroidism }\end{array}$ \\
$\begin{array}{c}\text { Metastasic renal } \\
\text { carcinoma }\end{array}$ & Hypo/hyperthyroidism \\
\hline
\end{tabular}

(127). As mentioned before, rifampicin can cause tubulointerstitial nephritis and hyperthyroidism (73).

\section{Effects of dialysis on thyroid function}

\section{Hemodialysis}

Most HD patients are euthyroid. Hypothyroidism is not infrequent in these patients. However, a diagnosis of hypothyroidism in $\mathrm{HD}$ patients should not be made solely on the basis of reduced $\mathrm{T}_{4}$ and $\mathrm{T}_{3}$ levels but requires documentation of substantial TSH elevation (TSH $>5 \mathrm{mU} / \mathrm{l}$ but $<20 \mathrm{mU} / \mathrm{l}$ may occur in $20 \%$ of uraemic patients and are more indicative of nonthyroidal illness than hypothyroidism). HD is associated with alterations in the concentration of circulating $\mathrm{TH}$, usually to a reduction in serum total and free $\mathrm{T}_{3}$ concentrations. This reduction is associated with systemic acidosis, time on dialysis, and some markers of endothelial damage and inflammation (128). Low TH may be a protective adaptation for nitrogen conservation and therefore inappropriate $\mathrm{TH}$ supplementation can result in excessive protein nitrogen wasting in these patients. HD influences the cellular transport of TH. This effect could act as a compensatory mechanism to neutralize the thyroid dysfunction in order to maintain euthyroid status (129).

Treatment with ablative dose of ${ }^{131} \mathrm{I}$ has been successfully used in the treatment of differentiated thyroid carcinoma in patients on HD (108, 130-136). HD removes more ${ }^{131}$ I from blood than from thyroid and helps to reduce radiation (132).

\section{Peritoneal dialysis}

The most common thyroid dysfunction in peritoneal dialysis (PD) patients is primary hypothyroidism, especially subclinical hypothyroidism (27.5\%) (137) This entity might be implicated in cardiac dysfunction in PD patients due to the fact that these patients show lower left ventricular ejection fractions and fractional shortening at endocardial levels compared with those with normal TSH levels (137). Other common alteration in thyroid function tests is low $\mathrm{T}_{3}$ syndrome (16\%) (138). The high protein loss induced by this type of dialysis could be related to an increased incidence of thyroid dysfunction (139). One of the important issues in PD patients is the continuous loss (due to the continuous nature of the method) of substantial amounts of proteins in the peritoneal cavity. Nevertheless, TBG concentrations remain within normal limits in these patients. When hypothyroidism develops, left ventricular function can be compromised but this is not specific to PD patients.

Because ${ }^{131} \mathrm{I}$ is eliminated primarily by the kidney some authors have recommended a reduction of $\sim$ fivefold in the dose of ${ }^{131}$ I used in the treatment of differentiated thyroid carcinoma in PD patients to avoid excessive radiation, primarily at bone marrow level $(140,141)$.

\section{Thyroid function and renal transplantation}

Kidney transplantation is associated with abnormalities in thyroid function, mainly a reduction in $\mathrm{T}_{3}$ concentrations (14-145). An independent relationship between $\mathrm{T}_{3}$ with different markers of endothelial dysfunction has been reported (143). Both thyroid volume and serum concentration of free $\mathrm{T}_{3}$ are correlated with the graft function (146-149). A positive correlation between serum creatinine and thyroid volume has been found. Patients with diminished values of $\mathrm{T}_{3}$ before transplantation are at increased risk of graft failure, thus suggesting that $\mathrm{T}_{3}$ quantification might be a potential marker for this risk $(144,146,147,150)$. However, treatment with $\mathrm{T}_{3}$ does not appear to prolong the half-life and function of the graft (151).

\section{Cancer, thyroid and kidney}

Patients who have survived to thyroid cancer have an increased risk of suffering a second malignancy, including renal cell carcinoma (152-154). A higher prevalence of genitourinary and kidney tumors has been reported in women with differentiated thyroid carcinoma (154). Coincidental thyroid and renal carcinomas have been reported in an isolated patient (155). This association could be related to the specific treatment of the disease or to a genetic predisposition. Finally, treatment with radiation therapy for a Wilms tumor of the kidney in childhood can be considered as a potential risk factor for developing a differentiated thyroid carcinoma (156).

Owing to the high vascularization of both organs it is not uncommon to observe a renal metastatic spread of a primary thyroid tumor and vice versa. Renal metastases have been reported in patients with papillary (157-163), follicular (164-169), and anaplastic (170) thyroid carcinomas. Kidney metastases from a thyroid carcinoma can appear between 7 and 30 years since diagnosis $(168,169,171)$. 
Kidney tumors may develop metastases at thyroid level, being between the first and fourth leading cause of thyroid metastases $(142,172-185)$. The presence of renal cell carcinoma metastases in the thyroid usually indicates a poor prognosis $(186,187)$, with a mean survival of about 5 years in $64 \%$ of cases. However, this type of metastases has also appeared between 5 and 19 years after nephrectomy (188-190).

Approximately, $65 \%$ of papillary thyroid carcinomas in children and adolescents express receptors for EPO. Tumors with expression of these receptors show more favorable prognostic indicators than those without them (191). Multiple endocrine neoplasia type 2A (thyroid medullary carcinoma, pheochromocytoma and primary hyperparathyroidism) has been also associated with renal dysplasia (192).

Furthermore, renal cell carcinomas that resemble the morphology of thyroid follicular carcinoma have been reported $(193,194)$. This histological type has not been recognized as a known form of renal cell carcinoma so far. It would be desirable to keep in mind this histological form to avoid inappropriate or unnecessary treatments (193). On the other hand, clear cell thyroid carcinomas have also been reported (195).

Some authors have observed not only changes in the role of nuclear receptors of $\mathrm{TH}$ in the renal cell carcinoma cells, but also aberrant patterns of expression of these receptors. It has been suggested that these abnormalities could contribute to the carcinogenesis of this type of tumor (196).

Finally, transplant patients show higher risk of oncogenesis than that found in the general population (197). The incidence of thyroid carcinoma in this group of patients has been found to be increased (198). In some populations, thyroid carcinoma is the fifth leading cause of malignancy in these patients (199).

\section{Thyroid function, morbidity, and mortality in kidney disease}

There is a relationship between plasma levels of $\mathrm{T}_{3}$ and various markers of inflammation, nutrition, and endothelial activation in patients with CKD (200). These patients show an association between low serum values of $\mathrm{T}_{3}$ with inflammation markers (elevated levels of high sensitivity $\mathrm{C}$-reactive protein, hs-CRP; interleukin 6, IL-6; and vascular adhesion molecule-1, VCAM-1) and nutrition (decrease of albumin and IGF-1), and cardiac function. The lower the concentration of $\mathrm{T}_{3}$ the greater the degree of inflammation, and poorer the nutritional status and cardiac function. Therefore, low $\mathrm{T}_{3}$ is associated with a survival disadvantage. The relationship between survival and $\mathrm{T}_{4}$ is less defined.

A reduction in total $T_{3}$, but not in free $T_{3}$ concentrations was associated with an increased allcause and cardiovascular mortality in euthyroid CKD patients (200). Total and free $\mathrm{T}_{3}$ behave as survival markers in patients with CKD both in HD (201) and in PD (202). For these reasons, some authors have recommended measuring $\mathrm{T}_{3}$ levels to assess the relationship between thyroid dysfunction and risk of mortality in this population. Finally, it has been recently reported that low levels of $\mathrm{T}_{3}$ before renal transplantation are associated with decreased survival of the graft (150).

Several factors, including malnutrition and intercurrent processes, may be involved in the reduction of serum $\mathrm{T}_{3}$ in uraemic patients. Fasting and disease alter iodothyronine deiodination, thus reducing peripheral production of $\mathrm{T}_{3}$. The presence of chronic protein malnutrition is associated with a reduction of binding protein synthesis and could reduce plasma total $\mathrm{T}_{3}$ concentration. TNF $\alpha$ and interleukin-1 inhibit the expression of type $15^{\prime}$-deiodinase, the enzyme responsible for $\mathrm{T}_{4}$ to $\mathrm{T}_{3}$ conversion in peripheral tissues. This would explain how chronic inflammation and vascular damage associated to CKD interfere with the normal process of $\mathrm{T}_{3}$ synthesis from $\mathrm{T}_{4}(142,200,201-203)$.

\section{Conclusions}

In summary, kidney and thyroid function and dysfunction are interrelated through several mechanisms.

From a clinical practical perspective, in patients with kidney disease, it is generally sufficient to use thyroid function tests commonly used in the clinic. However, to avoid mistakes in diagnosis, it is important to know the effects of hypothyroidism and hyperthyroidism on renal function, as well as the changes in thyroid function tests induced by acute and chronic kidney diseases. Drugs used in the treatment of thyroid and kidney diseases may induce changes in renal and thyroid physiology respectively. Treatment of $\mathrm{CKD}$ by $\mathrm{HD}$, $\mathrm{PD}$ or renal transplantation is also accompanied by specific changes in thyroid physiology. In patients with differentiated thyroid carcinoma, some modifications in the usual therapies may be necessary, especially in the dose of $\mathrm{I}^{131}$, in the presence of a decline in renal function. On the other hand, recent investigations have shown interesting relationships in neoplastic diseases affecting the thyroid and the kidney. A relationship between $\mathrm{T}_{3}$ levels and mortality has been proven in uraemic patients; however, the relationship between TSH and survival, well established in other population groups, has not been reported in patients with different degrees of kidney insufficiency. Further investigation in this field will provide new insights in our understanding of the biological significance of thyroid hormone changes in patients with kidney disease.

\section{Declaration of interest}

The authors declare that there is no conflict of interest that could be perceived as prejudicing the impartiality of the research reported. 


\section{Funding}

This research did not receive any specific grant from any funding agency in the public, commercial or not-for-profit sector.

\section{References}

1 Feinstein EI, Kaptein EM, Nicoloff JT \& Massry SG. Thyroid function in patients with nephrotic syndrome and normal renal function. American Journal of Nephrology 19822 70-76.

2 Kaptein EM, Quion-Verde H \& Massry SG. Hemodynamic effects of thyroid hormone. Contributions to Nephrology 198441 151-159.

3 Kaptein EM. Thyroid function in renal failure. Contributions to Nephrology $1986 \mathbf{5 0} 64-72$.

4 Kaptein EM, Feinstein EI \& Massry SG. Thyroid hormone metabolism in renal diseases. Contributions to Nephrology 1982 33 122-135.

5 Katz AI \& Lindheimer MD. Actions of hormones on the kidney. Annual Review of Physiology 197739 97-133.

6 Katz AI, Emmanouel DS \& Lindheimer MD. Thyroid hormone and the kidney. Nephron $197515223-249$.

7 Kaptein EM, Quion-Verde H, Chooljian CJ, Tang WW, Friedman PE, Rodriquez HJ \& Massry SG. The thyroid in endstage renal disease. Medicine 198867 187-197.

8 Braunlich $\mathrm{H}$. Thyroid hormones influencing renal electrolyte excretion in saline loaded rats of different ages. Physiologia Bohemoslovaca 198433 303-308.

9 Gattineni J, Sas D, Dagan A, Dwarakanath V \& Baum MG. Effect of thyroid hormone on the postnatal renal expression of NHE8. American Journal of Physiology. Renal Physiology 2008294 F198-F204.

10 Li Bok N, Fekete F \& Hársing L. Renal structural and functional changes and sodium balance in hypothyroid rats. Acta Medica Academiae Scientiarum Hungaricae 198239 219-225.

11 Katyare SS, Modi HR, Patel SP \& Patel MA. Thyroid hormoneinduced alterations in membrane structure-function relationships: studies on kinetic properties of rat kidney microsomal $\mathrm{Na}(+), \mathrm{K}(+)$-ATPase and lipid/phospholipid profiles. Journal of Membrane Biology 2007219 71-81.

12 Vargas F, Moreno JM, Rodríguez-Gómez I, Wangensteen R, Osuna A, Alvarez-Guerra M \& García-Estañ J. Vascular and renal function in experimental thyroid disorders. European Journal of Endocrinology 2006154 197-212.

13 Kumar J, Gordillo R, Kaskel FJ, Druschel CM \& Woroniecki RP. Increased prevalence of renal and urinary tract anomalies in children with congenital hypothyroidism. Journal of Pediatrics 2009 $154263-266$.

14 Capasso G, De Tommaso G, Pica A, Anastasio P, Capasso J, Kinne R \& De Santo NG. Effects of thyroid hormones on heart and kidney functions. Mineral and Electrolyte Metabolism 199925 $56-64$.

15 den Hollander JG, Wulkan RW, Mantel MJ \& Berghout A. Correlation between severity of thyroid dysfunction and renal function. Clinical Endocrinology 200562 423-427.

16 Liu XM, Bai Y \& Guo ZS. Study on urinary function and metabolism of water and electrolytes in primary hypothyroidism. Zhonghua Nei Ke Za Zhi 199029 299-302.

17 Emmanouel DS, Lindheimer MD \& Katz AI. Mechanism of impaired water excretion in the hypothyroid rat. Journal of Clinical Investigation $1974 \mathbf{5 4}$ 926-934.

18 Katz AI \& Lindheimer MD. Renal sodium- and potassiumactivated adenosine triphosphatase and sodium reabsorption in the hypothyroid rat. Journal of Clinical Investigation $1973 \mathbf{5 2}$ 796-804.

19 Capasso G, Kinne R, De Santo NG \& Giordano C. The use of micropuncture, isolated tubule, and vesicle technique in the study of the action of thyroid hormones on the proximal tubule function. Uremia Investigation 19859 151-157.
20 Holmes EW Jr \& DiScala VA. Studies on the exaggerated natriuretic response to a saline infusion in the hypothyroid rat. Journal of Clinical Investigation 197049 1224-1236.

21 Michael UF, Barenberg RL, Chavez R, Vaamonde CA \& Papper S. Renal handling of sodium and water in the hypothyroid rat. Clearance and micropuncture studies. Journal of Clinical Investigation 197251 1405-1412.

22 Lin HH \& Tang MJ. Thyroid hormone upregulates Na, K-ATPase alpha and beta mRNA in primary cultures of proximal tubule cells. Life Sciences $199760375-382$.

23 Vaamonde CA, Sebastianelli MJ, Vaamonde LS, Pellegrini EL, Watts RS, Klingler EL Jr \& Papper S. Impaired renal tubular reabsorption of sodium in hypothyroid man. Journal of Laboratory and Clinical Medicine 197585 451-466.

24 McCaffrey C \& Quamme GA. Effects of thyroid status on renal calcium and magnesium handling. Canadian Journal of Comparative Medicine $1984 \mathbf{4 8} 51-57$.

25 Hauger-Klevene JH, De Vito E \& Fasciolo JC. The effect of thyroid hormone on renin production and release by rat kidney slices. Acta Physiologica Latino Americana 197727 37-41.

26 Segarra AB, Ramírez M, Banegas I, Hermoso F, Vargas F, Vives F, Alba F, de Gasparo M \& Prieto I. Influence of thyroid disorders on kidney angiotensinase activity. Hormone and Metabolic Research 200638 48-52.

27 Dawson PA \& Markovich D. Regulation of the mouse Nas1 promoter by vitamin D and thyroid hormone. Pflugers Archiv: European Journal of Physiology 2002444 353-359.

28 Del Compare JA, Aguirre JA, Ibarra FR, Barontini M \& Armando I. Effects of thyroid hormone on the renal dopaminergic system. Endocrine 200115 297-303.

29 Villabona C, Sahun M, Roca M, Mora J, Gómez N, Gómez JM, Puchal R \& Soler J. Blood volumes and renal function in overt and subclinical primary hypothyroidism. American Journal of the Medical Sciences $1999 \mathbf{3 1 8}$ 277-280.

30 Kinsella J \& Sacktor B. Thyroid hormones increase $\mathrm{Na}^{+}-\mathrm{H}^{+}$ exchange activity in renal brush border membranes. PNAS 1985 82 3606-3610.

31 Davis RG, Madsen KM, Fregly MJ \& Tisher CC. Kidney structure in hypothyroidism. American Journal of Physiology 1983113 41-49.

32 Montenegro J, Gonzalez O, Saracho R, Aguirre R, Gonzalez O \& Martinez I. Changes in renal function in primary hypothyroidism. American Journal of Kidney Diseases 199627 195-198.

33 Kreisman SH \& Hennessey JV. Consistent reversible elevations of serum creatinine levels in severe hypothyroidism. Archives of Internal Medicine 1999159 79-82.

34 Mooraki A, Broumand B, Neekdoost F, Amirmokri P \& Bastani B. Reversible acute renal failure associated with hypothyroidism: report of four cases with a brief review of literature. Nephrology 20038 57-60.

35 Karanikas G, Schütz M, Szabo M, Becherer A, Wiesner K, Dudczak R \& Kletter K. Isotopic renal function studies in severe hypothyroidism and after thyroid hormone replacement therapy. American Journal of Nephrology 200424 41-45.

36 Al-Fifi S, Girardin C, Sharma A \& Rodd C. Moderate renal failure in association with prolonged acquired hypothyroidism in children. Acta Paediatrica $1999 \mathbf{8 8} 715-718$.

37 del-Rio CG, Tapia CL, Picazo AB, Ruiz Moreno JA, Hortas Nieto ML \& Romero GJ. Renal failure and acquired hypothyroidism. Pediatric Nephrology 200318 290-292.

38 Verhelst J, Berwaerts J, Marescau B, Abs R, Neels H, Mahler C \& De Deyn PP. Serum creatine, creatinine, and other guanidino compounds in patients with thyroid dysfunction. Metabolism 199746 1063-1067.

39 Nikolaeva AV \& Pimenov LT. Lipid metabolism and functional status of the kidney in hypothyroid patients depending on the phase of disease. Terapevticheskii Arkhiv 200274 20-23. 
40 van Welsem ME \& Lobatto S. Treatment of severe hypothyroidism in a patient with progressive renal failure leads to significant improvement of renal function. Clinical Nephrology $2007 \mathbf{6 7}$ 391-393.

41 Elgadi A, Verbovski P, Marcus C \& Berg UB. Long-term effects of primary hypothyroidism on renal function in children. Journal of Pediatrics 2008152 860-864.

42 Suher M, Koc E, Ata N \& Ensari C. Relation of thyroid disfunction, thyroid autoantibodies, and renal function. Renal Failure 2005 27 739-742.

43 Allon M, Harrow A, Pasque CB \& Rodriguez M. Renal sodium and water handling in hypothyroid patients: the role of renal insufficiency. Journal of the American Society of Nephrology 1990 $1205-210$.

44 Syme HM. Cardiovascular and renal manifestations of hyperthyroidism. Veterinary Clinics of North America. Small Animal Practice 200737 723-743.

45 Corrales JJ, Tabernero JM, Miralles JM \& Hernandez MT. Effects of subclinical hyperthyroidism on renal handling of water and electrolytes in patients with nodular goiter. Klinische Wochenschrift 199169 19-24.

46 Woeber KA. Thyrotoxicosis and the heart. New England Journal of Medicine 1992327 94-98.

47 Gurkan S, Dikman S \& Saland MJ. A case of autoimmune thyroiditis and membranoproliferative glomerulonephritis. Pediatric Nephrology 200924 193-197.

48 Valentin M, Bueno B, Gutierrez E, Martinez A, Gonzalez E, Espejo B \& Torres A. Membranoproliferative glomerulonephritis associated with autoimmune thyroiditis. Nefrologia $2004 \mathbf{2 4}$ $43-48$.

49 Grcevska L, Polenakovic M \& Petrusevska G. Membranous nephropathy associated with thyroid disorders. Nephron 2000 $86534-535$.

50 Weetman AP, Pinching AJ, Pussel BA, Evans DJ, Sweny P \& Rees AJ. Membranous glomerulonephritis and autoimmune thyroid disease. Clinical Nephrology 198115 50-51.

51 Enríquez R, Sirvent AE, Amorós F, Andrada E, Cabezuelo JB \& Reyes A. IgA nephropathy and autoimmune thyroiditis. Clinical Nephrology $2002 \mathbf{5 7} 406-407$.

52 Illies F, Wingen AM, Bald M \& Hoyer PF. Autoimmune thyroiditis in association with membranous nephropathy. Journal of Pediatric Endocrinology and Metabolism 200417 99-104.

53 O’Regan S, Fong JS, Kaplan BS, Chadarévian JP, Lapointe N \& Drummond KN. Thyroid antigen-antibody nephritis. Clinical Immunology and Immunopathology 19766 341-346.

54 Mizuno M, Hasegawa H, Fujishiro T, Murai S, Yanai T, Kojima K, Funahashi N, Ogawa T \& Kawashima S. Chronic thyroiditis complicated by nephrotic syndrome and marked hydroureteronephrosis. Nippon Jinzo Gakkai Shi 198729 561-569.

55 Akikusa B, Kondo Y, Iemoto Y, Iesato K \& Wakashin M. Hashimoto's thyroiditis and membranous nephropathy developed in progressive systemic sclerosis (PSS). American Journal of Clinical Pathology 198481 260-263.

56 Iwaoka T, Umeda T, Nakayama M, Shimada T, Fujii Y, Miura F \& Sato T. A case of membranous nephropathy associated with thyroid antigens. Japanese Journal of Medicine 198221 29-34.

57 Horvath F Jr, Teague P, Gaffney EF, Mars DR \& Fuller TJ. Thyroid antigen associated immune complex glomerulonephritis in Graves' disease. American Journal of Medicine 197967 901-904.

58 Tanwani LK, Lohano V, Broadstone VL \& Mokshagundam SP. Minimal change nephropathy and Graves' disease: report of a case and review of the literature. Endocrine Practice 20028 $40-43$.

59 Mahjoub S, Ben Dhia N, Achour A, Zebidi A, Frih A \& Elmay M. Primary hypothyroidism and glomerular involvement. Annales d'Endocrinologie 199152 289-292.

60 Ikeda K, Maruyama Y, Yokoyama M, Kato N, Yamanoto H, Kaguchi Y, Nakayama M, Shimada T, Tojo K, Kawamura T \& Hosoya T. Association of Graves' disease with Evans' syndrome in a patient with IgA nephropathy. Internal Medicine $2001 \mathbf{4 0}$ 1004-1010.
61 Dizdar O, Kahraman S, Gençtoy G, Ertoy D, Arici M, Altun B, Yasavul U \& Turgan C. Membranoproliferative glomerulonephritis associated with type 1 diabetes mellitus and Hashimoto's thyroiditis. Nephrology, Dialysis, Transplantation 200419 988-989.

62 Nishimoto A, Tomiyoshi Y, Sakemi T, Kanegae F, Nakamura M, Ikeda Y, Shimazu K \& Yonemitsu N. Simultaneous occurrence of minimal change glomerular disease, sarcoidosis and Hashimoto's thyroiditis. American Journal of Nephrology 200020 425-428.

63 Kagiyama S, Tsuruta H, Tominaga M, Morishita K, Doi Y \& Onoyama K. Minimal-change nephrotic syndrome and acute renal failure in a patient with aged onset insulin-dependent diabetes mellitus and autoimmune thyroiditis. American Journal of Nephrology 199919 369-372.

64 Jordan SC, Johnston WH \& Bergstein JM. Immune complex glomerulonephritis mediated by thyroid antigens. Archives of Pathology \& Laboratory Medicine 1978102 530-533.

65 Horikoshi T, Tamura J, Kaneko Y, Maezawa A, Kaji T, Matsushima T, Sawamura M, Murakami H, Yano S, Kubota K \& Naruse T. Membranous nephropathy associated with chronic thyroiditis. Nephron 199363246.

66 Calder EA, Penhale WJ, Barnes EW \& Irvine WJ. Evidence for circulating immune complexes in thyroid disease. BMJ 19746 30-31.

67 Brohee D, Delespesse G, Debisschop MJ \& Bonnyns M. Circulating immune complexes in various thyroid diseases. Clinical and Experimental Immunology 197936 379-383.

68 Ebihara I, Hirayama K, Usui J, Seki M, Higuchi F, Oteki T, Kobayashi M \& Yamagata K. Tubulointerstitial nephritis and uveitis syndrome associated with hyperthyroidism. Clinical and Experimental Nephrology 200610 216-221.

69 Paul E, Van Why S \& Carpenter TO. Hyperthyroidism: a novel feature of the tubulointerstitial nephritis and uveitis syndrome. Pediatrics 1999104 314-317.

70 Spronk PE, Weening JJ \& Schut NH. Eosinophilic tubulointerstitial nephritis associated with iridocyclitis and thyreoiditis. Netherlands Journal of Medicine 200159 35-38.

71 Hudde T, Heinz C, Neudorf U, Hoef S, Heiligenhaus A \& Steuhl KP. Tubulointerstitial nephritis and uveitis (TINU syndrome) comorbidity and complications in four patients. Klinische Monatsblätter für Augenheilkunde 2007219 528-532.

72 Sasaki H, Joh K, Ohtsuka I, Ohta H, Ohhashi T, Hoashi S, Takahashi T, Tokuda T, Koyama K \& Isogai Y. Interstitial nephritis associated with glomerulonephritis in a patient with Hashimoto's disease and idiopathic portal hypertension. Internal Medicine 199231 641-648.

73 Paydas S, Balal M, Karayaylali I \& Seyrek N. Severe acute renal failure due to tubulointerstitial nephritis, pancreatitis, and hyperthyroidism in a patient during rifampicin therapy. Advances in Therapy 200522 241-243.

74 Junglee NA, Scanlon MF \& Rees DA. Increasing thyroxine requirements in primary hypothyroidism: don't forget the urinalysis Journal of Postgraduate Medicine 200652 201-203.

75 Kaptein EM, Hoopes MT, Parise M \& Massry SG. rT3 metabolism in patients with nephrotic syndrome and normal GFR compared with normal subjects. American Journal of Physiology 1991260 E641-E650.

76 Chadha V \& Alon US. Bilateral nephrectomy reverses hypothyroidism in congenital nephrotic syndrome. Pediatric Nephrology 199913 209-211.

77 Etling N, Lenoir G \& Gehin-Fouque F. Thyroid function in a child with nephrotic syndrome evolving to renal failure (author's transl). Archives Françaises de Pédiatrie 198037 545-548.

78 Vachvanichsanong P, Mitarnun W, Tungsinmunkong K \& Dissaneewate P. Congenital and infantile nephrotic syndrome in Thai infants. Clinical Pediatrics 200544 169-174.

79 Muranjan MN, Kher AS, Nadkarni UB \& Kamat JR. Congenital nephrotic syndrome with clinical hypothyroidism. Indian Journal of Pediatrics 199562 233-235.

80 Matto T. Hypothyroidism in infants with nephrotic syndrome. Pediatric Nephrology 19948 657-659. 
81 Holmberg C, Antikainen M, Rönnholm K, Ala Houhala M \& Jalanko H. Management of congenital nephrotic syndrome of the Finnish type. Pediatric Nephrology 19959 87-93.

82 Kaptein EM, Levitan D, Feinstein EI, Nicoloff JT \& Massry SG. Alterations of thyroid hormone indices in acute renal failure and in acute critical illness with and without acute renal failure. American Journal of Nephrology 19811 138-143.

83 Bernet VJ. Reversible renal insufficiency attributable to thyroid hormone withdrawal in a patient with type 2 diabetes mellitus. Endocrine Practice 200410 339-344.

84 Kursat S, Alici T \& Colak HB. A case of rhabdomyolysis induced acute renal failure secondary to statin-fibrate-derivative combination and occult hypothyroidism. Clinical Nephrology $20056 \mathbf{4}$ 391-393.

85 Birewar S, Oppenheimer M \& Zawada ET Jr. Hypothyroid acute renal failure. South Dakota Journal of Medicine 200457 109-110.

86 Kar PM, Hirani A \& Allen MJ. Acute renal failure in a hypothyroid patient with rhabdomyolysis. Clinical Nephrology $200360428-429$.

87 Sekine N, Yamamoto M, Michikawa M, Enomoto T, Hayashi M, Ozawa E \& Kobayashi T. Rhabdomyolysis and acute renal failure in a patient with hypothyroidism. Internal Medicine 199332 269-271.

88 Kaptein EM. Thyroid hormone metabolism and thyroid diseases in chronic renal failure. Endocrine Reviews 199617 45-63.

89 Singh PA, Bobby Z, Selvaraj N \& Vinayagamoorthi R. An evaluation of thyroid hormone status and oxidative stress in undialyzed chronic renal failure patients. Indian Journal of Physiology and Pharmacology 200650 279-284.

90 Lim VS. Thyroid function in patients with chronic renal failure. American Journal of Kidney Diseases 200138 S80-S84.

91 Kaptein EM, Feinstein EI, Nicoloff JT \& Massry SG. Serum reverse triiodothyronine and thyroxine kinetics in patients with chronic renal failure. Journal of Clinical Endocrinology and Metabolism 198357 181-189.

92 Lim VS, Fang VS, Katz AI \& Refetoff S. Thyroid dysfunction in chronic renal failure. A study of the pituitary-thyroid axis and peripheral turnover kinetics of thyroxine and triiodothyronine. Journal of Clinical Investigation $197760522-534$.

93 Hegedüs L, Andersen JR, Poulsen LR, Perrild H, Holm B, Gundtoft E \& Hansen JM. Thyroid gland volume and serum concentrations of thyroid hormones in chronic renal failure. Nephron $198540171-174$.

94 Ramirez G, O’Neill W Jr, Jubiz W \& Bloomer HA. Thyroid dysfunction in uremia: evidence for thyroid and hypophyseal abnormalities. Annals of Internal Medicine $1976 \mathbf{8 4} 672-676$.

95 Weissel M \& Stummvoll HK. Disorders of hormone metabolism in chronic uremia. Klinische Wochenschrift $198361481-491$.

96 Kutlay S, Atli T, Koseogullari O, Nergizoglu G, Duman N \& Gullu S. Thyroid disorders in hemodialysis patients in an iodinedeficient community. Artificial Organs 200529 329-332.

97 Miki H, Oshimo K, Inoue H, Kawano M, Morimoto T, Monden Y, Yamamoto Y \& Kita S. Thyroid carcinoma in patients with secondary hyperparathyroidism. Journal of Surgical Oncology $199249168-171$.

98 Weetman AP, Weightman DR \& Scanlon MF. Impaired dopaminergic control of thyroid stimulating hormone secretion in chronic renal failure. Clinical Endocrinology 198115 451-456.

99 Witzke O, Wiemann J, Patschan D, Wu K, Philipp T Saller B et al. Differential T4 degradation pathways in young patients with preterminal and terminal renal failure. Hormone and Metabolic Research 200739 355-358.

100 Beyer HK, Schuster P \& Pressler H. Thyroid function in patients with kidney insufficiency requiring hemodialysis (author's transl). Nuklearmedizin 198019 283-287.

101 Lo JC, Chertow GM, Go AS \& Hsu CY. Increased prevalence of subclinical and clinical hypothyroidism in persons with chronic kidney disease. Kidney International 200567 1047-1052.
102 Wiederkehr MR, Kalogiros J \& Krapf R. Correction of metabolic acidosis improves thyroid and growth hormone axes in haemodialysis patients. Nephrology, Dialysis, Transplantation $2004191190-1197$.

103 Silverberg DS, Ulan RA, Fawcett DM, Dossetor JB, Grace M \& Bettcher K. Effects of chronic hemodialysis on thyroid function in chronic renal failure. Canadian Medical Association Journal 1973 $109282-286$.

104 Adler SM \& Wartofsky L. The nonthyroidal illness syndrome. Endocrinology and Metabolism Clinics of North America 200736 657-672.

105 Chonchol M, Lippi G, Salvagno G, Zoppini G, Muggeo M \& Targher G. Prevalence of subclinical hypothyroidism in patients with chronic kidney disease. Clinical Journal of the American Society of Nephrology 20083 1296-1300.

106 Bando Y, Ushiogi Y, Okafuji K, Toya D, Tanaka N \& Miura S. Nonautoimmune primary hypothyroidism in diabetic and nondiabetic chronic renal dysfunction. Experimental and Clinical Endocrinology and Diabetes $2002110408-415$.

107 Niemczyk S, Matuszkiewicz-Rowińska J, Stopiński M, Grochowski J, Sitkowska-Kurzec Z, Przedlacki J, Chojnowski K \& Królicki L. Management of hyperthyroidism with radioactive iodine in end-stage renal disease patients undergoing dialysis. Polskie Archiwum Medycyny Wewnetrznej $2004112931-936$.

108 Holst JP, Burman KD, Atkins F, Umans JG \& Jonklaas J. Radioiodine therapy for thyroid cancer and hyperthyroidism in patients with end-stage renal disease on hemodialysis. Thyroid 200515 1321-1331.

109 Kaynar K, Ozkan G, Erem C, Gul S, Yilmaz M, Sonmez B, Ozdemir F \& Ulusoy S. An unusual etiology of erythropoietin resistance: hyperthyroidism. Renal Failure 200729 759-761.

110 Sato K, Okamura K, Yoshinari M, Kuroda T, Ikenoue H, Okazawa K, Mizokami T, Onoyama K \& Fujishima M. Reversible primary hypothyroidism and elevated serum iodine level in patients with renal dysfunction. Acta Endocrinologica 1992126 253-259.

111 Brough $\mathrm{R}$ \& Jones $\mathrm{C}$. Iatrogenic iodine as a cause of hypothyroidism in infants with end-stage renal failure. Pediatric Nephrology 200621 400-402.

112 Sanai T, Inoue T, Okamura K, Sato K, Yamamoto K, Abe T, Node K, Tsuruya K \& Iida M. Reversible primary hypothyroidism in Japanese patients undergoing maintenance hemodialysis. Clinical Nephrology 200869 107-113.

113 Yu F, Chen M, Gao Y, Wang SX, Zou WZ, Zhao MH \& Wang HY. Clinical and pathological features of renal involvement in propylthiouracil-associated ANCA-positive vasculitis. American Journal of Kidney Diseases 200749 607-614.

114 Wang LC, Tsai WY, Yang YH \& Chiang BL. Methimazole-induced lupus erythematosus: a case report. Journal of Microbiology, Immunology, and Infection 200336 278-281.

115 Calañas-Continente A, Espinosa M, Manzano-García G, Santamaría R, Lopez-Rubio F \& Aljama P. Necrotizing glomerulonephritis and pulmonary hemorrhage associated with carbimazole therapy. Thyroid 200515 286-288.

116 Allagui MS, Hfaiedh N, Croute F, Guermazi F, Vincent C, Soleilhavoup JP \& El Feki A. Side effects of low serum lithium concentrations on renal, thyroid, and sexual functions in male and female rats. Comptes Rendus Biologies 2005328 900-911.

117 Bendz H \& Aurell M. Adverse effects of lithium treatment and safety routines. Lakartidningen 2004101 1902-1906.

118 Kirk AD, Hale DA, Swanson SJ \& Mannon RB. Autoimmune thyroid disease after renal transplantation using depletional induction with alemtuzumab. American Journal of Transplantation $200661084-1085$.

119 Stein EM \& Rivera C. Transient thyroiditis after treatment with lenalidomide in a patient with metastatic renal cell carcinoma. Thyroid $200717681-683$.

120 Umemoto S, Izumi K \& Kanno H. Two cases of hyperthyroidism induced by interferon-alpha therapy for renal cell carcinoma. Hinyokika Kiyo 200753 225-229. 
121 Feldman DR, Martorella AJ, Robbins RJ \& Motzer RJ. Re: hypothyroidism in patients with metastatic renal cell carcinoma treated with sunitinib. Journal of the National Cancer Institute 200799 974-975.

122 Rini BI, Tamaskar I, Shaheen P, Salas R, Garcia J, Wood L, Reddy S, Dreicer R \& Bukowski RM. Hypothyroidism in patients with metastatic renal cell carcinoma treated with sunitinib. Journal of the National Cancer Institute 200799 81-83.

123 Garfield DH, Hercbergs A \& Davis PJ. Re: Hypothyroidism in patients with metastatic renal cell carcinoma treated with sunitinib. Journal of the National Cancer Institute $2007 \mathbf{9 9}$ 975-976.

124 Grossmann M, Premaratne E, Desai J \& Davis ID. Thyrotoxicosis during sunitinib treatment for renal cell carcinoma. Clinical Endocrinology $2008 \mathbf{6 9} 669-672$.

125 Iglesias P. Repercusiones del tratamiento con amiodarona sobre la función tiroidea y su manejo actual. Endocrinología y Nutrición 200754 354-370.

126 Martino E, Bartalena L, Bogazzi F \& Braverman LE. The effects of amiodarone on the thyroid. Endocrine Reviews 200122 240-254.

127 Morales AI, Barata JD, Bruges M, Arévalo MA, González de Buitrago JM, Palma P, Branco P \& Pérez-Barriocanal F. Acute renal toxic effect of amiodarone in rats. Pharmacology $\mathcal{E}$ Toxicology 200392 39-42.

128 Malyszko J, Malyszko JS, Pawlak K \& Mysliwiec M. Thyroid function, endothelium, and inflammation in hemodialyzed patients: possible relations? Journal of Renal Nutrition $2007 \mathbf{1 7}$ 30-37.

129 Rodrigues MC, Santos GM, da Silva CA, Baxter JD, Webb P, Lomri N, Neves FA, Ribeiro RC \& Simeoni LA. Thyroid hormone transport is disturbed in erythrocytes from patients with chronic renal failure on hemodialysis. Renal Failure 200426 461-466.

130 Modarresifar H, Almodovar S, Bass WB \& Ojha B. Radiation safety protocol for high dose ${ }^{131}$ I therapy of thyroid carcinoma in patients on hemodialysis for chronic renal failure. Health Physics 200792 S45-S49.

131 Alevizaki C, Molfetas M, Samartzis A, Vlassopoulou B, Vassilopoulos C, Rondogianni P, Kottou S, Hadjiconstantinou V \& Alevizaki M. Iodine 131 treatment for differentiated thyroid carcinoma in patients with end stage renal failure: dosimetric, radiation safety, and practical considerations. Hormones 20065 276-287.

132 Courbon F, Caselles O, Zerdoud S, Duthil P, Regis H, Berry I \& Caron P. Iodine-131 pharmacokinetics in patients on hemodialysis for end stage renal disease: clinical implications. Quarterly Journal of Nuclear Medicine and Molecular Imaging $200650363-370$.

133 Sinsakul M \& Ali A. Radioactive ${ }^{131}$ I use in end-stage renal disease: nightmare or nuisance? Seminars in Dialysis 200417 53-56.

134 Wang TH, Lee CH, Tseng LM \& Liu RH. The management of welldifferentiated thyroid cancer with end-stage renal disease. Endocrine $200321227-231$.

135 Magne N, Magne J, Bracco J \& Bussiere F. Disposition of radioiodine (131)I therapy for thyroid carcinoma in a patient with severely impaired renal function on chronic dialysis: a case report. Japanese Journal of Clinical Oncology 200232 202-205.

136 Jiménez RG, Moreno AS, Gonzalez EN, Simón FJL, Rodriguez JR, Jimenez JC, Córdoba MH, Albertino RV \& Jimenez RA. Iodine-131 treatment of thyroid papillary carcinoma in patients undergoing dialysis for chronic renal failure: a dosimetric method. Thyroid 200111 1031-1034.

137 Kang EW, Nam JY, Yoo TH, Shin SK, Kang SW \& Han SH. Clinical implications of subclinical hypothyroidism in continuous ambulatory peritoneal dialysis patients. American Journal of Nephrology 200828 908-913.

138 Díez JJ, Iglesias P \& Selgas R. Pituitary dysfunctions in uraemic patients undergoing peritoneal dialysis: a cross sectional descriptive study. Advances in Peritoneal Dialysis 199511 218-224.
139 Robey C, Shreedhar K \& Batuman V. Effects of chronic peritoneal dialysis on thyroid function tests. American Journal of Kidney Diseases 198913 99-103.

140 Kaptein EM, Levenson H, Siegel ME, Gadallah M \& Akmal M. Radioiodine dosimetry in patients with end-stage renal disease receiving continuous ambulatory peritoneal dialysis therapy. Journal of Clinical Endocrinology and Metabolism $2000 \mathbf{8 5}$ 3058-3064.

141 Toubert ME, Michel C, Metivier F, Peker MC \& Rain JD. Iodine131 ablation therapy for a patient receiving peritoneal dialysis. Clinical Nuclear Medicine 200126 302-305.

142 Tauchmanovà L, Carrano R, Musella T, Orio F, Sabbatini M, Lombardi G, Fenzi G, Federico S \& Colao A. Thyroid function and morphology after a successful kidney transplantation. Journal of Endocrinological Investigation $200629625-632$.

143 Malyszko J, Malyszko JS, Pawlak K \& Mysliwiec M. Possible relations between thyroid function, endothelium, and kidney and liver function in kidney allograft recipients. Transplantation Proceedings 200638 3509-3513.

144 Reinhardt W, Misch C, Jockenhövel F, Wu SY, Chopra I, Philipp T, Reinwein D, Eigler FW \& Mann K. Triiodothyronine (T3) reflects renal graft function after renal transplantation. Clinical Endocrinology $1997 \mathbf{4 6} 563-569$.

145 Junik R, Wlodarczyk Z, Masztalerz M, Odrowaz-Sypniewska G, Jendryczka E \& Manitius J. Function, structure, and volume of thyroid gland following allogenic kidney transplantation. Transplantation Proceedings $2003352224-2226$.

146 Lebkowska U, Brzósko S, Lapiński R, Adamczyk M, Janica JR, Małyszko J, Ostapowicz R, Gacko M \& Walecki J. Thyroid volume and hormone response in the early kidney transplants. Medical Science Monitor 200410 51-54.

147 Łebkowska U, Małyszko J, Brzósko S, Łebkowski W, Małyszko JS, Janica J, Kowalewski R, Gacko M, Myśliwiec M \& Walecki J. Renal artery resistance index, thyroid hormones, and thyroid volume in the early kidney transplants recipients. Transplantation Proceedings 200638 62-65.

148 Lebkowska U, Malyszko J \& Mysliwiec M. Thyroid function and morphology in kidney transplant recipients, hemodialyzed, and peritoneally dialyzed patients. Transplantation Proceedings 2003 35 2945-2948.

149 Lebkowska U, Malyszko J, Brzosko S, Walecki J \& Mysliwiec M. Thyroid gland function in patients after renal transplantation. Transplantation Proceedings 200234 596-597.

150 Rotondi M, Netti GS, Rosati A, Mazzinghi B, Magri F, Ronconi E, Becherucci F, Pradella F, Salvadori M, Serio M, Romagnani P \& Chiovato L. Pretransplant serum FT3 levels in kidney graft recipients are useful for identifying patients with higher risk for graft failure. Clinical Endocrinology 200868 220-225.

151 Acker CG, Flick R, Shapiro R, Scantlebury VP, Jordan ML, Vivas C, Greenberg A \& Johnson JP. Thyroid hormone in the treatment of post-transplant acute tubular necrosis (ATN). American Journal of Transplantation 20022 57-61.

152 Subramanian S, Goldstein DP, Parlea L, Thabane L, Ezzat S, Ibrahim-Zada I, Straus S, Brierley JD, Tsang RW, Gafni A, Rotstein L \& Sawka AM. Second primary malignancy risk in thyroid cancer survivors: a systematic review and meta-analysis. Thyroid 200717 1277-1288.

153 Canchola AJ, Horn-Ross PL \& Purdie DM. Risk of second primary malignancies in women with papillary thyroid cancer. American Journal of Epidemiology $2006 \mathbf{1 6 3} 521-527$.

154 Berthe E, Henry-Amar M, Michels JJ, Rame JP, Berthet P, Babin E, Icard P, Samama G, Galateau-Sallé F, Mahoudeau J \& Bardet S. Risk of second primary cancer following differentiated thyroid cancer. European Journal of Nuclear Medicine and Molecular Imaging $200431685-691$.

155 Rai RS, Deb P, Rai R, Gupta E \& Panayach JS. Synchronous primary triple neoplasia (renal cell carcinoma and prostate cancer in combination with thyroid neoplasm). Report of an unusual case. Minerva Urologica e Nefrologica $2007 \mathbf{5 9}$ 451-454. 
156 Vezzadini C, Cremonini N, Sforza A, Presutti L \& Chiarini V. Treated Wilm's tumor in childhood as potential risk factor for second thyroid cancer. Panminerva Medica $2002 \mathbf{4 4}$ 275-277.

157 Sarma DP \& Simmons GT. Intraglomerular metastases from papillary carcinoma of the thyroid. Journal of the Louisiana State Medical Society 1989141 26-28.

158 Liou MJ, Lin JD, Chung MH, Liau CT \& Hsueh C. Renal metastasis from papillary thyroid microcarcinoma. Acta Oto-Laryngologica $2005125438-442$.

159 Ruggiero FP, Frauenhoffer EE \& Stack BC Jr. Papillary thyroid cancer with an initial presentation of abdominal and flank pain. American Journal of Otolaryngology 200526 142-145.

160 Gamboa-Dominguez A \& Tenorio-Villalvazo A. Metastatic follicular variant of papillary thyroid carcinoma manifested as a primary renal neoplasm. Endocrine Pathology $1999 \quad 10$ 256-268.

161 Inahara M, Mikami K, Tobe T, Suzuki H \& Itou H. A case of thyroid cancer metastasizing to the bilateral kidneys. Hinyokika Kiyo 200248 315-317.

162 Abe K, Hasegawa T, Onodera S, Oishi Y \& Suzuki M. Renal metastasis of thyroid carcinoma. International Journal of Urology $20029656-658$.

163 Smallridge RC, Castro MR, Morris JC, Young PR, Reynolds JC, Merino MJ \& Sarlis NJ. Renal metastases from thyroid papillary carcinoma: study of sodium iodide symporter expression. Thyroid 200111 795-804.

164 von FC, Beer G, Gratz KF \& Galanski M. Renal metastases from follicular thyroid cancer on SPECT/CT. Clinical Nuclear Medicine 200732 751-752.

165 Kumar A, Nadig M, Patra V, Srivastava DN, Verma K \& Bal CS. Adrenal and renal metastases from follicular thyroid cancer. British Journal of Radiology 200578 1038-1041.

166 Iwai H, Ohno Y, Ito H, Kiyokawa T \& Aoki N. Renal rupture associated with a poorly differentiated follicular thyroid carcinoma metastasizing to the thigh muscle, lung and kidney. Internal Medicine 200544 848-852.

167 Regojo Balboa JM, Sánchez Zalabardo D, Rioja Zuazu J, Fernández Montero JM, López Ferrandis J, Zudaire Bergera JJ, Rosell Costa D, Robles García JE \& Berián Polo JM. Follicular carcinoma of the thyroid manifested initially as asymptomatic primary renal neoplasm. Actas Urologicas Españolas 200428 308-310.

168 Matei DV, Verweij F, Scardino E, Rocco B, Renne G, Tradati N \& De Cobelli O. Late solitary thyroid carcinoma metastasis to the kidney: a case report. Anticancer Research 200323 561-564.

169 Moudouni S, En-Nia I, Rioux-Leclerc N, Patard JJ, Guille F \& Lobel B. Renal metastasis of thyroid carcinoma. Progrés en Urologie 200111 670-672.

170 Oktay MH, Smolkin MB, Williams M \& Cajigas A. Metastatic anaplastic carcinoma of the thyroid mimicking squamous cell carcinoma: report of a case of a challenging cytologic diagnosis. Acta Cytologica 200650 201-204.

171 Insabato L, Di VD, De RG, Prezioso D, Corcione F \& Terracciano LM. Renal metastasis from thyroid carcinoma 35 years after detection of the primary tumor. Tumori 2003 89 99-101.

172 Bhalla R, Popp A \& Nassar A. Case report: metastatic renal carcinoid to the thyroid diagnosed by fine needle aspiration biopsy. Diagnostic Cytopathology 200735 597-600.

173 Papi G, Fadda G, Corsello SM, Corrado S, Rossi ED, Radighieri E, Miraglia A, Carani C \& Pontecorvi A. Metastases to the thyroid gland: prevalence, clinicopathological aspects and prognosis: a 10-year experience. Clinical Endocrinology 2007 $66565-571$.

174 Cichon S, Anielski R, Konturek A, Barczynski M \& Cichon W. Metastases to the thyroid gland: seventeen cases operated on in a single clinical center. Langenbeck's Archives of Surgery 2006391 581-587.
175 Iesalnieks I, Woenckhaus M, Glockzin G, Schlitt HJ \& Agha A. Renal cell carcinoma metastases to the thyroid gland - report of 3 cases and review of the literature. Zentralblatt für Chirurgie $2006131235-239$.

176 Wada N, Hirakawa S, Rino Y, Hasuo K, Kawachi K, Nakatani Y, Inui K \& Takanashi Y. Solitary metachronous metastasis to the thyroid from renal clear cell carcinoma 19 years after nephrectomy: report of a case. Surgery Today 2005 35 483-487.

177 Ronckers CM, McCarron P \& Ron E. Thyroid cancer and multiple primary tumors in the SEER cancer registries. International Journal of Cancer 2005117 281-288.

178 Mirallié E, Rigaud J, Mathonnet M, Gibelin H, Regenet N, Hamy A, Bretagnol F, de Calan L, Le Néel JC \& Kraimps JL. Management and prognosis of metastases to the thyroid gland. Journal of the American College of Surgeons $2005 \mathbf{2 0 0}$ 203-207.

179 Qian L, Pucci R, Castro CY \& Eltorky MA. Renal cell carcinoma metastatic to Hurthle cell adenoma of thyroid. Annals of Diagnostic Pathology 20048 305-308.

180 Dequanter D, Lothaire P, Larsimont D, de Saint-Aubain de Somerhausen N \& Andry G. Intrathyroid metastasis: 11 cases. Annales d'Endocrinologie 200465 205-208.

181 Wood K, Vini L \& Harmer C. Metastases to the thyroid gland: the Royal Marsden experience. European Journal of Surgical Oncology 200430 583-588.

182 Koo HL, Jang J, Hong SJ, Shong Y \& Gong G. Renal cell carcinoma metastatic to follicular adenoma of the thyroid gland. A case report. Acta Cytologica $2004 \mathbf{4 8} 64-68$.

183 Giuffrida D, Ferraù F, Pappalardo A, Aiello RA, Bordonaro R, Cordio S, Giorgio CG \& Squatrito S. Metastasis to the thyroid gland: a case report and review of the literature. Journal of Endocrinological Investigation 200326 560-563.

184 May M, Marusch F, Kaufmann O, Seehafer M, Helke C, Hoschke B \& Gastinger I. Solitary renal cell carcinoma metastasis to the thyroid gland-a paradigm of metastasectomy? Der Chirurg; Zeitschrift für Alle Gebiete der Operativen Medizen $2003 \mathbf{7 4}$ 768-774.

185 Heffess CS, Wenig BM \& Thompson LD. Metastatic renal cell carcinoma to the thyroid gland: a clinicopathologic study of 36 cases. Cancer 200295 1869-1878.

186 Gerges AS, Shehata SR \& Gouda IA. Metastasis to the thyroid gland; unusual site of metastasis. Journal of the Egyptian National Cancer Institute 200618 67-72.

187 Benoit L, Favoulet P, Arnould L, Margarot A, Franceschini C, Collin F, Fraisse J, Cuisenier J \& Cougard P. Metastatic renal cell carcinoma to the thyroid gland: report of seven cases and review of the literature. Annales de Chirurgie 2004129 218-223.

188 Uzel C, Coskun H, Terzioglu T \& Aras N. Thyroid metastasis from renal cell carcinoma eight years after radical nephrectomy: a case report. Kulak Burun Boğaz Ihtisas Dergisi 200311 $152-156$.

189 Kihara M, Yokomise H \& Yamauchi A. Metastasis of renal cell carcinoma to the thyroid gland 19 years after nephrectomy: a case report. Auris, Nasus, Larynx 200431 95-100.

190 Ambrosiani L, Declich P, Bellone S, Tavani E, Pacilli P, Guarneri A, Rovellini P \& Bianchi A. Thyroid metastases from renal clear cell carcinoma: a cyto-histological study of two cases. Advances in Clinical Pathology 20015 11-16.

191 Eccles TG, Patel A, Verma A, Nicholson D, Lukes Y, Tuttle RM \& Francis GL. Erythropoietin and the erythropoietin receptor are expressed by papillary thyroid carcinoma from children and adolescents. Expression of erythropoietin receptor might be a favorable prognostic indicator. Annals of Clinical and Laboratory Science $200333411-422$.

192 McIntyre E, Bond P, Douglas F, Lennard T, Peaston R \& Perros P. Multiple endocrine neoplasia type 2A: an unusual clinical presentation and association with renal dysplasia. Cancer Genetics and Cytogenetics $2003 \mathbf{1 4 1} 157-159$. 
193 William S, Irmgard V, Michael G \& Gregor M. Thyroid follicular carcinoma-like renal tumor: a case report with morphologic, immunophenotypic, cytogenetic, and scintigraphic studies. Virchows Archiv $2008 \mathbf{4 5 2} 91-95$.

194 Jung SJ, Chung JI, Park SH, Ayala AG \& Ro JY. Thyroid follicular carcinoma-like tumor of kidney: a case report with morphologic, immunohistochemical, and genetic analysis. American Journal of Surgical Pathology 200630 411-415.

195 Owecki M, Stawny B, Drews M \& Sowinski J. Primary clear cell carcinoma of the thyroid - case report. Polskie Archiwum Medycyny Wewnetrznej 2004112 849-851.

196 Kamiya Y, Puzianowska-Kuznicka M, McPhie P, Nauman J, Cheng SY \& Nauman A. Expression of mutant thyroid hormone nuclear receptors is associated with human renal clear cell carcinoma. Carcinogenesis 200223 25-33.

197 Adami J, Gäbel H, Lindelöf B, Ekström K, Rydh B, Glimelius B, Ekbom A, Adami HO \& Granath F. Cancer risk following organ transplantation: a nationwide cohort study in Sweden. British Journal of Cancer 200389 1221-1227.

198 Pond F, Serpell JW \& Webster A. Thyroid cancer in the renal transplant population: epidemiological study. ANZ Journal of Surgery 200575 106-109.

199 Wang CX, Liu LS, Chen LZ, Chen SY, Wu PG, Fei JG, Qiu J, Deng SX, Zheng KL, Ji YL, Zhu LY, Shen QR \& He XS. Characteristics of neoplasm occurrence and the therapeutic effect of sirolimus in South Chinese kidney transplant recipients. Transplantation Proceedings 200638 3536-3539.

200 Carrero JJ, Qureshi AR, Axelsson J, Yilmaz MI, Rehnmark S, Witt MR, Bárány P, Heimbürger O, Suliman ME, Alvestrand A, Lindholm B \& Stenvinkel P. Clinical and biochemical implications of low thyroid hormone levels (total and free forms) in euthyroid patients with chronic kidney disease. Journal of Internal Medicine 2007262 690-701.

201 Zoccali C, Mallamaci F, Tripepi G, Cutrupi S \& Pizzini P. Low triiodothyronine and survival in end-stage renal disease. Kidney International 2006 70 523-528.

202 Enia G, Panuccio V, Cutrupi S, Pizzini P, Tripepi G, Mallamaci F \& Zoccali C. Subclinical hypothyroidism is linked to micro-inflammation and predicts death in continuous ambulatory peritoneal dialysis. Nephrology, Dialysis, Transplantation 200722 538-544.

203 Zoccali C, Tripepi G, Cutrupi S, Pizzini P \& Mallamaci F. Low triiodothyronine: a new facet of inflammation in end-stage renal disease. Journal of the American Society of Nephrology 200516 2789-2795.

Received 9 December 2008

Accepted 15 December 2008 